\title{
Competence Practices on Contemporary Business Education: Teaching \& Learning
}

\author{
Adekemi Dorcas Fadun Ph.D
}

\begin{abstract}
This Paper has set out to examine the Competence Practices on Contemporary Business Education: Teaching \& Learning. The curriculum is not static, therefore is expected to undergo changes so as to meet the ever changing and emerging needs of the society. In relation to this, the paper examined the components of business education programme in the contemporary society, identified the challenges encountered in executing competency practice in business education teaching and learning and also determined the extent to which competency practices enhance teaching and learning of business education. Through a study conducted in the state College of Education in Osun State Ila Orangun, primary data were retrieved through questionnaire, with a sample size of 68 respondents. The three research questions raised as well as one null hypothesis postulated. were analyzed using mean for the first and second objective, while Pearson product moment correlation was used for the third objective, and the null hypotheses were tested at 0.05 level of significance using regression analysis. The findings of the study among others revealed that competency practice has an effect on effective teaching and learning of business education, where effective recruitment was the only competency practice that influence effective teaching and learning of business education. Also, academic quality of lecturers was the major challenge which affects the Competence outcome on effective teaching and learning of business education. The paper among other things recommends adequate staffing of qualified academics.
\end{abstract}

Keywords - Competence, Business Education, Teaching and learning, Recruitment.

\section{INTRODUCTION}

Business education according to Oliver (2011), is the sum total of the knowledge, skills and attitude that are required for successfully promoting and administering business enterprises. Promoting an organization however requires possessing the knowledge, skill and attitude to rightly manage the affairs of the organization, ensuring that all activities be carried out could be well accounted for and also sustaining the organization by marketing the output of the organization which brings back revenue to the organization for continuous operation.

Conversely, to ensure a smooth promotion of the organization, there is a need to imbibe competency in the practices of business education teaching and learning. Competency entails inputs, or underlying attributes, required of a person to achieve competent performance (Hoffman, 1999). It

Adekemi Dorcas Fadun Ph.D , Department of Business Education,Osun State College of Education, Ila Orangun, Osun State, Nigeria often serves as the basis for skill standards that specify the level of knowledge, skills, and abilities required for success in the workplace as well as potential measurement criteria for assessing competency attainment. Furthermore, Laci (2016) expressed that competencies are abilities, behaviour, knowledge and skills that impact the success of employees and organization. They are foundations of high performance.

Teaching in the view of Filani (2010) is a systematic process of imparting desirable knowledge, values, attitude and skills to the learner, and for teaching to be effective, competency needs to be in place so that a systematic, rational and organized process of translating knowledge, skills, attitude and values in accordance with certain professional principles can be attained (Uwameiye \& Ogunbamerun, 2012).

Utoware and Kren-Ikidi (2013) citing American Vocational Association (AVA) in Osuala (2009) posits business education as a programme of instruction which consist of two parts, which are office education(a vocational education programme for office careers through initial, refresher and upgrading education leading to employability and advancement in office occupation), and general business education (a programme to provide students with information and competencies which are needed by all in managing personal and business affairs and in using the services of the business world). However, this study intend to look at business education to encompasses management, accountability and marketing.

Management is fundamental to any business on how to plan in order to get things done, organize the business to be efficient, lead and motivate employees and also put in place control to make sure plan are followed and business goals are being achieved (Robbins \& Coutlers, 2012). Also according to ethics activist Geoff Hunt, accountability is the readiness or preparedness to give an explanation or justification that are relevant to others (stakeholders) for one's judgments, intentions, acts and omissions when appropriately called upon to, While marketing from the view of Adetayo (2006) is simply a process of identifying, creating delivery of satisfier within a societal constraint profitably in exchange for something of value in the arena of business competition

In ensuring effective teaching and learning of business education, the following competency practices will be looked into:

- Effective Recruitment: Richardson describe recruitment as "the set of activities and processes used to legally obtain a sufficient number of qualified people at the right place and time 
so that the people and the organization can select each other in their own best short and long term interests". This serve as a base for the value to be inculcated in the teaching and learning process.

- Quality Assurance: This is important because for quality of education to be guaranteed, emphasis should be placed on the quality of teaching and learning in order to ensure impressiveness, efficiency and productivity of education (Utoware \& Kren-Ikidi, 2013)

- Good Interpersonal Relationship: Interpersonal relationship is the social link between two or more persons (Egifuga, 2011), which involves maintaining relationships that are mutually satisfying, fulfilling, rewarding and enjoyable, for all parties (Stein \& Book, 2006). this cannot be avoided as it is a skill that unite different parties together, which is also necessary for mutual achievement of certain goals.

- Change Adaptability: Nothing stays constant, which makes adaptability to change a necessary competence practice. Adaptability is a change in behavior characterized by innovative or creative approaches in anticipation of, or response to, environmental changes appropriate to solve problems (Boylan $\&$ Turner, 2017). It is a reactive response to new things which tend to emerge whether foreseen or unforeseen.

\section{StATEMENT OF PROBLEM}

Teaching and learning process is compliment of the value to be retrieved after knowledge is being transferred. And in the search for effective execution of assigned duties and responsibilities, most especially organization and business related, interested individual search for knowledge required to make them achieve this, of which education in tertiary institution is one of the avenue followed in achieving this, whereby related courses are being studied, with the aim of being awarded a certified qualification to enable them fit in to work effectively. However, authors like Essia (2012) and Nwazor (2012) have described the failure of the education offered in tertiary institutions especially in the business education programmes to prepare students and graduates for real life situations, which the colleges of education are not also left behind in this. Graduate of business education tend not to be able to align themselves with the basic objectives of studying the course. This result into under-development of most employees as the necessary skills, knowledge, abilities needed to carry out their assigned duties, to manage both human and non-human resources, account effectively for the operation of the organization and also market the output of their organization are not be learned.

It was however observed that this was as a result of theoretical concertation of business education teaching in most tertiary institution, lagging behind ensuring practice execution of the curriculum for effective practice of graduate from the field. Also, change is not left behind in this as Utoware \& Kren-Ikidi, (2013) opined that the emergence of new technologies such as the computer, word processor, the internet, automated teller machines, reprographic machines, micrographic machines, accounting machines, modern telephonic systems including handset and multimedia, among others, have not only revolutionized the office environment but have also brought changes in the ways people are doing things. However, this has not been complemented in the contemporary teaching and learning of business education curriculum.

This study however intends to inculcate some competency practices as an avenue to ensure effective teaching and learning process.

\section{RESEARCH QUESTION}

From the problem stated above, the following research question were generated for the study:

1. What are the components of business education programme in the contemporary society?

2. Why are competency practice not attainable in business education teaching and learning?

3. To what extent does competency practices enhance teaching and learning of business education.

\section{RESEARCH OBJECTIVES}

1. Examine the components of business education programme in the contemporary society

2. Identify the challenges encountered in executing competency practice in business education teaching and learning.

3. Determine the extent to which competency practices enhance teaching and learning of business education.

\section{RESEARCH HYPOTHESIS}

$\mathrm{H}_{01}$ : there is no significant effect of the identified competency practices on effective business education teaching and learning.

\section{Methodology}

This study adopts the descriptive research design, and was conducted among staff and students of the Department of Business Education, Osun state college of Education, Ila-Orangun, Osun State, Nigeria. The primary source of data was used, where questionnaire was selected as the major instrument used in extracting needed data from the respondent. The study has a total population of 482, involving 22 staff and 460 students. All the 22 staff were purposively selected due to the few populations, while 46 students determined using the $10 \%$ rule of thumb from the total student population were selected using the simple random sampling technique. Thus, the total sample size for this study is 68 . From the 68 respondents selected, only 62 respondents comprising of all the 22 staff and 40 students responded adequately to the questionnaire and data retrieved from them were used in carrying out the analysis of the study. The research questions were analyzed using descriptively using mean for the first and second objective, while the third objective was analyzed using Pearson product moment correlation. And the hypothesis was tested using regression analysis. 


\section{RESULTS AND DISCUSSION}

\section{A. Analysis of Research Question}

Research Question 1: What are the components of business education programme in the contemporary society?

TABLE I: DESCRIPTIVE STATISTICS OF THE COMPONENTS OF BUSINESS EDUCATION PROGRAMMES

\begin{tabular}{|c|c|c|c|c|c|}
\hline & $\mathrm{N}$ & Minimum & Maximum & Mean & $\begin{array}{l}\text { Std. } \\
\text { Deviation }\end{array}$ \\
\hline Management & 62 & 1.00 & 5.00 & 4.7097 & .68681 \\
\hline Accountability & 62 & 1.00 & 5.00 & 4.6935 & 69161 \\
\hline Marketing & 62 & 2.00 & 5.00 & 4.2742 & .89019 \\
\hline $\begin{array}{ll}\text { Valid } & \mathrm{N} \\
\text { (listwise) } & \end{array}$ & 62 & & & & \\
\hline
\end{tabular}

Source: Field Survey, 2018

The data in table 1 above shows the mean value of the identified component of business education programme. Management has a mean value of 4.7097, Accountability has a mean value of 4.6935, and Marketing has a mean value of 4.2742. Thus, all the identified component of business education programme in this study has a high mean value of above the average of 3.0. This implies that Management, Accountability and Marketing was supported by the respondents as components that makes up the business education programme in the contemporary society.

Research Question 2: Identify the challenges encountered in executing competency practice in business education teaching and learning.

TABLE II: DESCRIPTIVE STATISTICS OF CHALLENGES ENCOUNTERED IN EXECUTING COMPETENCY PRACTICE IN BUSINESS EDUCATION TEACHING AND

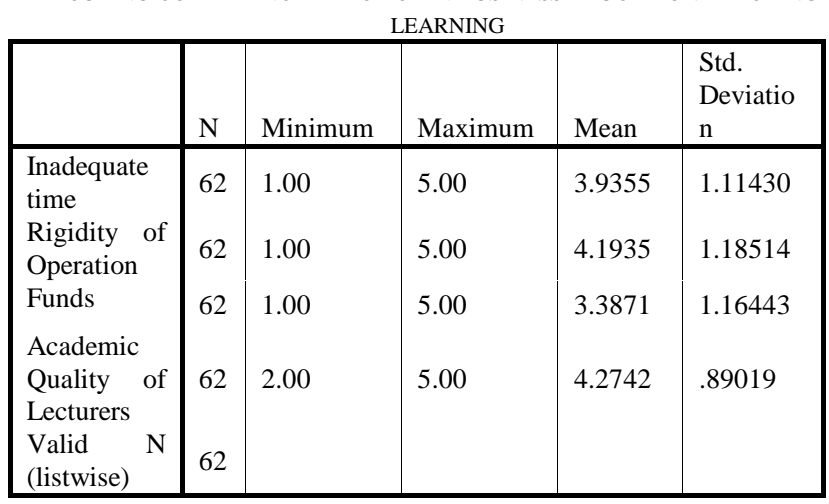

Source: Field Survey, 2018

The data in table 2 above shows the mean value of the challenges encountered in executing competency practice in business education teaching and learning. Inadequate time has a mean value of 3.9255 , Rigidity of operation has a mean value of 4.1935, Funds has a mean value of 3.3871 and Academic quality of lecturers has a mean value of 4.2742 . Thus, all the identified challenges encountered in executing competency practice in business education teaching and learning was supported by the respondents as it all has mean value above the average mean of 3.0. However, academic quality of lecturer was seen as the major challenge.

Research Question 3: Determine the extent to which competency practices enhance teaching and learning of business education

TABLE III: PEARson PRODUCT MOMENT CORRELATIONS SUMMARY SHOWING RELATIONSHIP BETWEEN COMPETENCY PRACTICE AND EFFECTIVE BUSINESS EDUCATION TEACHING AND LEARNING

\begin{tabular}{|c|c|c|c|}
\hline & & $\begin{array}{l}\text { Effective } \\
\text { Business } \\
\text { Education } \\
\text { Teaching } \\
\text { and } \\
\text { Learning } \\
\end{array}$ & $\begin{array}{l}\text { Competency } \\
\text { Practice }\end{array}$ \\
\hline $\begin{array}{l}\text { Pearson } \\
\text { Correlation }\end{array}$ & $\begin{array}{l}\text { Effective Business } \\
\text { Education } \\
\text { Teaching } \\
\text { Learning }\end{array}$ & 1.000 & .600 \\
\hline & $\begin{array}{l}\text { Competency } \\
\text { Practice }\end{array}$ & .600 & 1.000 \\
\hline $\begin{array}{l}\text { Sig. } \\
\text { (1-tailed) }\end{array}$ & $\begin{array}{l}\text { Effective Business } \\
\text { Education } \\
\text { Teaching and } \\
\text { Learning }\end{array}$ & & .000 \\
\hline \multirow{3}{*}{$\mathrm{N}$} & $\begin{array}{l}\text { Competency } \\
\text { Practice }\end{array}$ & .000 & \\
\hline & $\begin{array}{l}\text { Effective Business } \\
\text { Education } \\
\text { Teaching } \\
\text { Learning }\end{array}$ & 62 & 62 \\
\hline & $\begin{array}{l}\text { Competency } \\
\text { Practice }\end{array}$ & 62 & 62 \\
\hline
\end{tabular}

Source: Field Survey, 2018

Table 3 above reveals that there is a significant relationship between competency practice and effective business education teaching and learning: $r(60)=.600, \mathrm{p}<0.01$. The table further reveals that competency practices has a positive relationship with effective business education teaching and learning: i.e. the higher the influence of competency practice, the more effective teaching and learning of business education will become. Coefficient of determination $(\mathrm{r} 2=0.36)$ reveals that competency practices accounts for $36 \%$ in the variation of effective business education teaching and learning. Thus, competency practices had a low influence on effective business education teaching and learning.

\section{B. Test of Hypothesis}

$\mathrm{H}_{01}$ : there is no significant effect of the identified competency practices on effective business education teaching and learning. 
TABLE IV: MODEL SUMMARY FOR COMPETENCY PRACTICES AND EFFECTIVE BUSINESS EDUCATION TEACHING AND LEARNING

\begin{tabular}{|c|c|c|c|c|c|c|c|c|c|}
\hline Model & $\mathrm{R}$ & R Square & $\begin{array}{l}\begin{array}{l}\text { Adjusted } \\
\text { Square }\end{array} \\
\end{array}$ & $\begin{array}{l}\text { Std. Error of } \\
\text { the Estimate }\end{array}$ & Change Statistics & & & & \\
\hline & & & & & R Square Change & F Change & df1 & df 2 & Sig. F Change \\
\hline 1 & $.787(a)$ & .620 & .593 & 1.62116 & .620 & 23.247 & 4 & 57 & .000 \\
\hline
\end{tabular}

a Predictors: (Constant), effective recruitment, quality assurance, interpersonal relationship, change adaptability

Source: Field Survey, 2018

TABLE V: ANOVA TABLE FOR COMPETENCY PRACTICES AND EFFECTIVE BUSINESS EDUCATION TEACHING AND LEARNING.

\begin{tabular}{|c|c|c|c|c|c|c|}
\hline \multicolumn{2}{|c|}{ Model } & $\begin{array}{l}\text { Sum of } \\
\text { Squares }\end{array}$ & df & $\begin{array}{l}\text { Mean } \\
\text { Square }\end{array}$ & $\mathrm{F}$ & Sig. \\
\hline \multirow[t]{3}{*}{1} & Regression & 244.389 & 4 & 61.097 & 23.247 & $.000(a)$ \\
\hline & Residual & 149.804 & 57 & 2.628 & & \\
\hline & Total & 394.194 & 61 & & & \\
\hline
\end{tabular}

a Predictors: (Constant), effective recruitment, quality assurance, interpersonal relationship, change adaptability

b Dependent Variable: effective Business education teaching and learning Source: Field Survey, 2018

TABLE IV.V: COEFFICIENTS ANALYSIS FOR COMPETENCY PRACTICES AND EFFECTIVE BUSINESS EDUCATION TEACHING AND LEARNING.

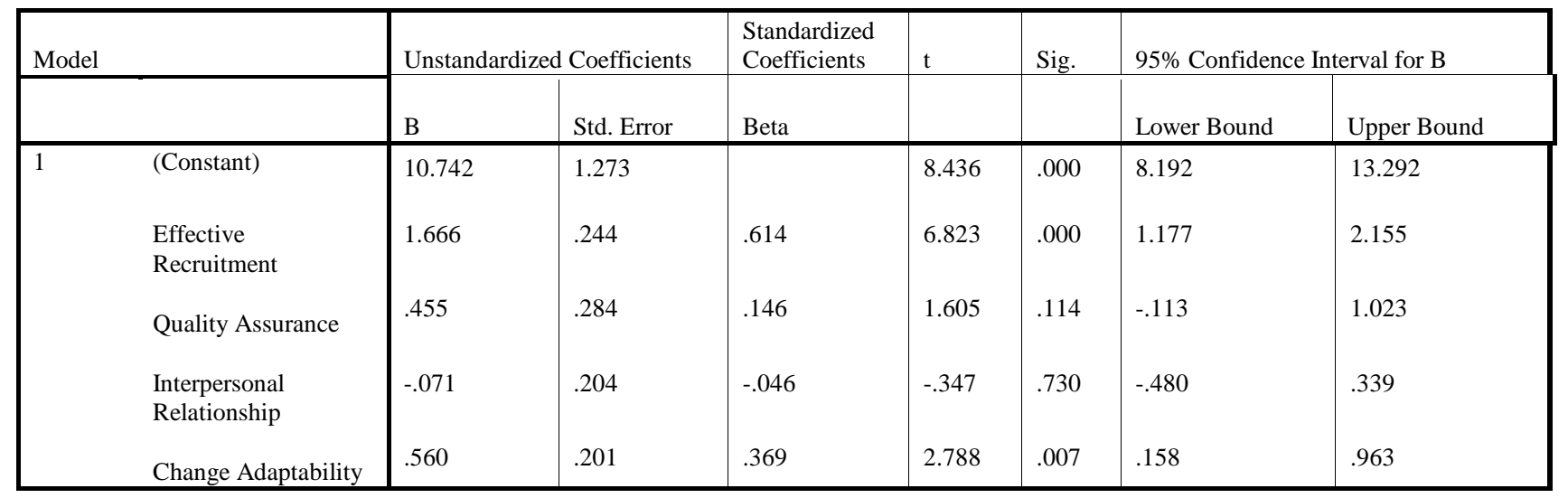

a Dependent Variable: effective business education teaching and learning Source: Field Survey, 2018

The result of shown in table 4,5, and 6 above revealed that exists a significant joint contribution of the competency practices on the effective teaching and learning business education. Therefore, the null hypothesis is rejected and the alternative accepted. The table revels the multiple $\mathrm{R}=.787$, $\mathrm{R} 2=620$, Adjusted R2=593. This suggest that the predictor jointly accounted for $59.3 \%$ (.593) variance in the prediction of effective business education teaching and learning. The remaining $40.7 \%$ variance is as a result of variables beyond the scope of the study. The ANOVA table reveals that competency practices have significant effect on effective business education teaching and learning: $F(4,57)=23.247, \mathrm{p}<0.01$. However, only one out of the four practices which is effective recruitment $(.614,6.823, \mathrm{p}<0.01)$ is a relative significant predictor of effective business education teaching and learning, while quality assurance $(.146,1.605, \mathrm{p}>0.05)$, interpersonal relationship $(-.046,-.347, \mathrm{p}>0.05)$ and change adaptability $(.369,2.788, \mathrm{p}>0.05)$. Thus, this implies that a unit change in effective recruitment will increase the effectiveness of business education teaching and learning.

\section{CONCLUSION}

The findings of this study revealed that competency practice has an influence on ensuring effective teaching and learning of business education. The major competency practice was effective recruitment. Thus, when there is a default in ensuring recruitment of qualified lecturer from unset, it became very difficult for all other practices to be effective as there exist multi collinearity among the competency practice variables. As quality of academic lecturers was seen as a major challenge in executing competency practice in teaching and learning of business education, this occurs as a result of wrong recruitment, where non-qualified lecturers with necessary qualities are employed. This limits the effectiveness of the learning outcome and also affects the quality of graduate produce in business education.

In the light of the findings of this study, this researcher recommends that in recruiting academic staff, all necessary qualification needed for effective teaching of business education should be possessed by the candidate, and also the 
candidate to be employed must possess the ability to adapt to change, have a good interpersonal relationship, assurance of quality dissemination of duties being assigned and also should be flexible enough to adapt to change. This will enable execution of competent practice as all necessary skill, knowledge and ability needed to execute competent practice in teaching and learning of business education will be indulged in the recruitment process.

\section{REFERENCES}

[1] Boylan, S. A. \& Turner, K. A. (2017). Developing Organizational Adaptability for Complex Environment, Journal of Leadership Education , DOI: 10.12806/V16/I2/T2.

[2] Egifugha, A. U. (2011) Teaching and learning of Social Skills In Schools: Implications to Social Health. Being a paper presented at the 1st International biennial Conference on Teaching and Learning held at the Federal College of Education Technical, Omoku Rivers State Nigeria.

[3] Essia, U. (2012). Entrepreneurial culturing of formal education programmes in Nigeria. Journal of Sustainable Society, 1 (2), 52-62.

[4] Filani, E.O. (2010). Teacher education in a democratized Nigeria: challenges and way forward. Being a Lead Paper Presented at the National Conference of South-West Colleges of Education Academic Staff Union (COEASU), Ondo.

[5] Geoff Hunt, "Accountability" Retrieved from http://www.freedomtocare.org/.

[6] Hoffmann, T. (1999). The meanings of competency. Journal of European Industrial Training, 23(6), 275-286. https://doi.org/10.1108/03090599910284650

[7] Laci, 1. (2012). Competency management: challenges and benefits. Retrieved from https://trainingmag.com/competency-management-challenges-and-benef its/

[8] Nwazor, J. C. (2012). Capacity building, entrepreneurship and sustainable development. Journal of Emerging Trends in Educational Research and Policy Studies (JETERAPS), 3 (1), 51-54.

[9] OECD (2016). Innovating Education and Educating for Innovation: The Power of Digital Technologies and Skills, OECD Publishing, Paris. http://dx.doi.org/10.1787/9789264265097-en

[10] Oliver, Y.B (2011). The impact of cooperative education (SIWES) on the performance of business students in practical Vocational business courses. Multidisciplinary Journal of Academic Excellence, 17(2), 78 85.

[11] Richardson, M. A. Recruitment Strategies Managing/Effecting The Recruitment Process retrieved from unpan1.un.org/intradoc/groups/public/documents/UN/UNPAN021814.p df, $14 / 09 / 2018$.

[12] Robbins, S. \& Coulter, M. (2012). Management (11 edition). Upper Saddle River : Pearson Education, Inc. ISBN 978-0-13-216384-2

[13] Stein, S. J. \& Book, H. E. (2006). The EQ Edge: Emotional Intelligence and Your Success. Mississauga: John Wiley \& Sons Canada. Ltd.

[14] Uwameiye, R. \& Ogunbamerun, M. (2012). Professional and Technical Competencies Needed by Teachers of Business Studies in Junior Secondary Schools in Ondo State, Nigeria, International Journal of Academic Research in Progressive Education and Development 1(4), ISSN: 2226-6348, pp 209-214

[15] Utoware, J. D. \& Kren-Ikidi, P.C. (2013). New Technologies in Business Education for Instruction and Practice: Imperatives for Quality Assurance, American International Journal of Contemporary Res. 